\title{
Interactions of genotype, housing and dietary calcium in layer performance, eggshell quality and tibia characteristics
}

\author{
E. Tůmovái\# ${ }^{1 \#}$ J. Vlčková ${ }^{1}$, V. Charvátová ${ }^{1}$, O. Drábek², V. Tejnecký ${ }^{2}$ \\ M. Ketta ${ }^{1}$ \& D. Chodová ${ }^{1}$ \\ ${ }^{1}$ Department of Animal Husbandry, Czech University of Life Sciences Prague, Kamýcká 129, \\ 16521 Prague 6 Suchdol, Czech Republic \\ ${ }^{2}$ Department of Soil Science and Soil Protection, Czech University of Life Sciences Prague, \\ 16521 Prague 6 Suchdol, Czech Republic
}

(Received 3 March 2016; Accepted 31 June 2016; First published online 31 August 2016)

\author{
Copyright resides with the authors in terms of the Creative Commons Attribution 2.5 South African Licence. \\ See: http://creativecommons.org/licenses/by/2.5/za \\ Condition of use: The user may copy, distribute, transmit and adapt the work, but must recognise the authors and the South African \\ Journal of Animal Science.
}

\begin{abstract}
The study was designed to evaluate the interactions in performance, eggshell quality and tibia traits of two laying hen genotypes, namely a commercial hybrid, Lohmann (LSL), and a traditional breed, the Czech Hen $(\mathrm{CH})$, housed in conventional cages and on litter, and fed two levels of dietary calcium $(\mathrm{Ca})(3.5 \%$ vs. 3.0\%). A significant interaction between genotype, housing and $\mathrm{Ca}$ was determined in egg weight. The heaviest eggs were laid by LSL hens housed in cages and fed 3.0\% $\mathrm{Ca}(61.8 \mathrm{~g})$, and the lightest laid by $\mathrm{CH}$, also in cages on $3.0 \% \mathrm{Ca}(47.3 \mathrm{~g})$. Eggshell strength and shell weight were significantly affected by threeway interaction. Czech hens kept in cages and fed $3.0 \%$ Ca produced the strongest shells $\left(4480 \mathrm{~g} / \mathrm{cm}^{2}\right)$, whereas the $\mathrm{CH}$ in cages on $3.5 \% \mathrm{Ca}$ had the weakest $\left(3665 \mathrm{~g} / \mathrm{cm}^{2}\right)$ shells. Hens housed on litter had significantly stronger tibias than hens housed in cages (485 vs. $397 \mathrm{~N}$ ). With respect to genotype, tibias were stronger in $\mathrm{CH}$. Housing and level $\mathrm{Ca}$ in feed had a significant effect on tibia weight. However, none of these factors affected tibia thickness or ash content. Tibia Ca content was higher in caged birds than in those on litter. The results of the study show that interaction between housing, genotype and Ca resulted in large differences in measurements of egg weight and eggshell quality. Tibia characteristics were less affected by the treatments, and no interactions were evident in the variables.
\end{abstract}

Keywords: Cage, calcium level, Czech Hen, laying hens, litter, Lohmann

\#Corresponding author: tumova@af.czu.cz

\section{Introduction}

Commercially available laying hen genotypes have been selected over many decades for egg production and egg size. This selection has resulted in differences between modern commercial hybrids and traditional pure breeds. On the other hand, traditional breeds have adapted to environmental conditions of the region of their origin and may therefore be suitable in alternative housing systems. There are limited studies in which traditional breeds and commercial hybrids have been compared. Hocking et al. (2003) observed that commercial lines displayed greater rates and persistency of lay, and laid larger eggs, which contained more albumen of higher quality than traditional breeds. In contrast, eggshell weight and thickness have not changed over time. Anderson et al. (2004) did not find differences in eggshell thickness, percentage or specific gravity between historic strains and commercial laying stock. This correlates with findings by Hocking et al. (2003), who reported that there were no differences in eggshell percentage between commercial strains and pure breeds, but a greater eggshell weight was found in the commercial lines. Commercial lines had weak bones with relatively little genetic variation for eggshell strength compared with traditional lines.

Genetic improvement in egg production with good eggshell quality has increased Ca requirements (Farmer et al., 1986). However, little attention has been paid to the Ca requirement in traditional breeds that could be used in alternative production systems. Traditional breeds have often been used in organic production (Rizzi \& Chiericato, 2010; Rizzi \& Marangon, 2012), but little is known about the quality of their product and their requirements.

The effect of housing systems on eggshell quality is not uniform, and there is no clear indication of which production system results in eggs with the best shell quality (Holt et al., 2011). Inconsistent results 
could be explained through the interaction of housing system and genotype (Leyendecker et al., 2001; Van den Brand et al., 2004; Singh et al., 2009; Tůmová et al., 2011). Housing system affects bone characteristics, with reports that hens kept in cages have weaker bones than those in alternative housing (Abrahamsson \& Tauson, 1997; Leyendecker et al., 2001; Lichovníková \& Zeman, 2008). Leyendecker et al. (2001) found a negative correlation between eggshell stability and bone strength. Again, there is lack of data on housing system and bone thickness and strength in traditional breeds.

Calcium is the major structural element in the eggshell, and plays an important role in medullary bone formation. The medullary bone is a reserve of $\mathrm{Ca}$ for eggshell formation and a common indicator of $\mathrm{Ca}$ metabolism in laying hens. The prevalence of broken bones is related to the high requirement for $\mathrm{Ca}$ deposition in eggshells (Hocking et al., 2003). The tibia is known to contain marked amounts of medullary bone (Leyendecker et al., 2005). This bone is turned over according to a daily egg cycle and contributes $35 \%$ to $40 \%$ of the $\mathrm{Ca}$ for eggshell formation (Kim et al., 2012). Calcium requirements can also depend on the genotype of laying hens. The NRC (1994) recommends a dietary Ca content of 3.25\% for Leghorn type and $3.6 \%$ for brown laying hens. However, there are no data for traditional breeds. It is possible to assume that traditional breeds have lower $\mathrm{Ca}$ requirements than hybrids owing to their lower egg production and higher feed intake. Feed Ca level affects bone strength. Cheng \& Coon (1990) observed a linear relationship between increasing $\mathrm{Ca}$ intake from $2.0 \mathrm{~g} / \mathrm{d}$ to $4.5 \mathrm{~g} / \mathrm{d}$ and bone breaking strength. Similarly, Nascimento et al. (2014) found a beneficial effect of increasing dietary $\mathrm{Ca}(2.85 \%-5.25 \%)$ on tibia breaking strength. Świątkiewicz et al. (2015) demonstrated a linear decrease in relative Ca retention with increasing dietary Ca, and confirmed that at low dietary $\mathrm{Ca}$ concentration, layers are able to maximize their utilization of dietary $\mathrm{Ca}$. Cufadar et al. (2011) and Neijat et al. (2011) suggested that housing system should also be taken into account when determining the correct $\mathrm{Ca}$ requirements in the diets of laying hens. Lichovníková \& Zeman (2008) observed that $\mathrm{Ca}$ intake was similar in enriched cages and on the floor system. However, a lower proportion of $\mathrm{Ca}$ was deposited in the eggshells on the floor system and in enriched cages compared with conventional cages. Tibia strength was also higher on the floor system.

The aim of the present study was to evaluate interactions in performance, eggshell quality and tibia traits of two laying hen genotypes (a commercial hybrid, the Lohmann (LSL) and a traditional breed, the Czech Hen (CH)), housed in conventional cages and on litter, and fed two dietary Ca levels (3.5\% and $3.0 \%)$.

\section{Materials and Methods}

The experiment was approved by the Ethics Committee of the Czech University of Life Sciences Prague and the Central Commission for Animal Welfare at the Ministry of Agriculture of the Czech Republic.

The experiment with 126 laying hens, LSL, and 126 of the traditional breed, $\mathrm{CH}$, was carried out in the second half of the laying cycle from 40 to 60 weeks old. In the first phase of the laying cycle, hens were kept under the same conditions. The $\mathrm{CH}$ is the original layer breed that was developed in the middle of the nineteenth century in the Czech Republic. Their live weight is $1.8 \mathrm{~kg}$ to $2.2 \mathrm{~kg}$, while egg yield and egg weight (58 $\mathrm{g}$ on average) are low, with late sexual maturity. The hens have partridge-coloured plumage, a white skin and white eggshells. The breed is in the conservation programme of genetic resources of the Czech Republic. Laying hens were housed in conventional Eurovent cages $\left(550 \mathrm{~cm}^{2} / \mathrm{hen}, 3\right.$ hens in a cage, 22 cages per genotype, 11 cages per group) and in 12 littered pens with floor space of 7 hens $/ \mathrm{m}$ (six pens for each genotype, three pens per group). Laying hens in both housing systems were fed commercial feed mixtures, differing only in Ca content, namely 3.5\% and 3.0\%. The composition of the feed mixtures is given in Table 1. Feed and water were available ad libitum throughout the experiment. In the diet, dry matter was determined by drying samples at $105^{\circ} \mathrm{C}$ to a constant weight. AOAC International procedures (2005) were used to determine the crude protein (954.01) and ash (942.05) contents. Gross energy was determined by combustion with an adiabatic bomb calorimeter (Laget MS10A, Laget, CZ). Calcium content was analysed using the AOAC method 965.17, based on vanad-molybden reagent and spectrophotometry analysis on Solaar M6 apparatus (TJA Solutions, Cambridge, UK). Environmental conditions were in accordance with laying hen requirements. The daily photoperiod consisted of $15 \mathrm{~h}$ light and $9 \mathrm{~h}$ darkness (lights were turned on at 4:00 and off at 19:00). During the experiment, egg production and feed consumption were recorded daily. Data of egg collection were used to calculate hen-day egg production (Şekeroğlu et al., 2014) and expressed as egg production (\%). Based on feed intake, daily Ca consumption was calculated.

Eggs for quality assessment were collected on two consecutive days in a four-week interval. The first collection was at 40 weeks old. All eggs in each cage or littered pen were collected, but defective eggs such as those with double yolks or abnormal shells were excluded (total 1320 eggs). The eggs were weighed individually, and shell strength was determined by the shell-breaking method using a QC-SPA device (TSS York, UK) on the equatorial region. Shell weight was determined after three days of drying at room temperature. The eggshell proportion was calculated from the egg weight and eggshell weight. The eggshell 
weight was determined after drying. Eggshell thickness was calculated as the mean of three measurements in the equatorial region, after removing the eggshell membranes, using a QCT shell thickness micrometer (TSS York, UK). Eggshell density was calculated according to the formula eggshell density $=($ shell weight/shell surface) $\times 100$ (Ahmed et al., 2005) and the surface area of each egg was calculated using the equation suggested by Thomson et al. (1985), namely egg surface $=4.67$ (egg weight $)^{2 / 3}$.

Table 1 Composition of experimental diets and nutrient content on dry matter basis

\begin{tabular}{lcc}
\hline Item(\%) & Feed mixture 3.0\% calcium & Feed mixture 3.5\% calcium \\
\hline Wheat & 35.8 & 35.5 \\
Maize & 31.0 & 33.3 \\
Soya extracted meal & 15.5 & 15.5 \\
Fish meal & 1.5 & 1.5 \\
Wheat bran & 2.5 & 2.5 \\
Alfalfa meal & 3.0 & 2.0 \\
Rapeseed oil & 3.0 & 3.0 \\
Limestone & 6.8 & 8.0 \\
Dicalcium phosphate & 1.0 & 1.0 \\
Sodium chloride & 0.2 & 0.2 \\
Vitamin-mineral premix ${ }^{\mathrm{a}}$ & 0.5 & 0.5 \\
Analysed content of nutrients & & \\
Crude protein (g/kg) & 155.2 & 153.7 \\
AME (MJ/kg) & 11.54 & 11.58 \\
Calcium (\%) & 3.03 & 3.48 \\
Phosphorus (\%) & 0.56 & 0.56 \\
& & \\
\hline
\end{tabular}

\footnotetext{
${ }^{a}$ Vitamin-mineral premix provided per kg of diet: retinyl acetate $8000 \mathrm{IU}$; vitamin $\mathrm{D}_{3} 2250 \mathrm{IU}$; vitamin E $15 \mathrm{mg}$; menadione $1.5 \mathrm{mg}$; thiamine $1.5 \mathrm{mg}$; riboflavin $4 \mathrm{mg}$; pyridoxine $2 \mathrm{mg}$; cobalamine $0.01 \mathrm{mg}$; niacinamide $20 \mathrm{mg}$; Ca pantothenate $6 \mathrm{mg}$; biotin $0.06 \mathrm{mg}$; folic acid $0.4 \mathrm{mg}$; choline chloride $250 \mathrm{mg}$; betaine $50 \mathrm{mg}$; DL-methionine 0.3 g; Co 0.3 mg; Cu 6 mg; Fe 30 mg; I 0.7 mg; Mn 60 mg; Zn 50 mg; Se 0.2 mg.

AME: apparent metabolizable energy.
}

At 50 weeks old, six birds per group were randomly selected to determine tibia characteristics. The selected hens were slaughtered by cervical dislocation after electric stunning. After slaughtering, both tibia were removed completely from the carcass and cleaned of connective tissues. Weight, length, strength and thickness were evaluated on the right tibia. Tibia strength was measured with a QC-SPA device (TSS York, UK) and thickness with a QCT micrometer (TSS York, UK). Ash and Ca were analysed using the left tibia. The tibia bones were incinerated $\left(500{ }^{\circ} \mathrm{C}\right.$ ) and crushed. From each sample, $0.5 \mathrm{~g}$ was weighed and $5 \mathrm{~mL}$ $35 \% \mathrm{HCl}$ (p.a. Penta s.r.o., CZ) was added with $10 \mathrm{gtt} 65 \% \mathrm{HNO}_{3}$ (p.a. Penta s.r.o., CZ). The mixture was heated for $15 \mathrm{~min}$. and subsequently diluted 200 times, using re-distilled water. Samples prior to analysis were further diluted and acidified with $2 \mathrm{M} \mathrm{HNO}_{3}$ and lanthanized (La). Concentration of La in each sample was adjusted to $10 \mathrm{mg} / \mathrm{mL}$. Ca content was determined by FAAS (AA280FS Varian, Australia) under standard conditions. Data quality was controlled and assured by standard laboratory procedures, including blanks and certified reference material.

The results of the experiment were evaluated with ANOVA, using the GLM procedure of SAS (SAS, 2013). The model included the effects of genotype, housing system and feed Ca level, as well as the interactions among them. A $P$-value of $P<0.05$ was considered significant for all measurements.

\section{Results}

The main effects of laying hen genotype, housing system, feed Ca level, their interactions on egg production, feed intake, $\mathrm{Ca}$ intake and egg weight are presented in Table 2. The results show that all production parameters for $\mathrm{CH}$ were lower compared with LSL $(P<0.001)$. Neither housing system nor Ca 
level in the feed had an effect on the rate of lay. In the cage system, feed intake $(P<0.001)$ and Ca intake $(P$ $<0.001)$ were lower, but egg weight was higher $(P<0.001)$. The higher Ca level increased both Ca intake $(P$ $<0.002)$ and egg weight $(P<0.033)$.

There was no interaction between genotype, housing and Ca level $(P>0.05)$ in rate of lay, feed or Ca intake. However, a three-way interaction was observed in egg weight $(P<0.001)$. The heaviest eggs were laid by LSL hens housed in cages and fed $3 \% \mathrm{Ca}$, while the lightest eggs were laid by $\mathrm{CH}$, also in cages and on $3 \% \mathrm{Ca}$. The two genotypes reacted differently, depending on the housing and Ca level. An increase in dietary $\mathrm{Ca}$ resulted in an increase in egg weight in $\mathrm{CH}$ housed in cages and in LSL housed on the floor, whereas this increase in Ca caused egg weight to fall in $\mathrm{CH}$ housed on the floor and in LSL hens in cages.

Table 2 Main effects of genotype, housing system and dietary calcium (Ca) level, and their interactions on egg production, feed intake, calcium intake and egg weight

\begin{tabular}{|c|c|c|c|c|c|c|}
\hline Factor & Item & $\begin{array}{l}\text { Calcium } \\
(\%)\end{array}$ & $\begin{array}{c}\text { Egg } \\
\text { production } \\
(\%)\end{array}$ & $\begin{array}{l}\text { Feed intake } \\
\text { (g) }\end{array}$ & $\begin{array}{l}\text { Ca intake } \\
(g)\end{array}$ & $\begin{array}{l}\text { Egg weight } \\
\text { (g) }\end{array}$ \\
\hline \multirow[t]{2}{*}{ Genotype } & Czech Hen & & $18.2^{b}$ & $106^{b}$ & $3.45^{b}$ & $49.5^{b}$ \\
\hline & Lohmann & & $86.2^{\mathrm{a}}$ & $142^{\mathrm{a}}$ & $4.63^{a}$ & $60.4^{a}$ \\
\hline RMSE & & & 10.3 & 30.8 & 1.08 & 6.15 \\
\hline \multirow[t]{2}{*}{ Housing } & Cage & & 50.4 & $89.3^{b}$ & $2.90^{b}$ & $55.3^{a}$ \\
\hline & Litter & & 54.2 & $159^{\mathrm{a}}$ & $5.18^{a}$ & $54.6^{b}$ \\
\hline RMSE & & & 36.6 & 24.9 & 0.84 & 7.41 \\
\hline \multirow[t]{2}{*}{$\mathrm{Ca}$} & 3.0 & & 53.9 & 125 & $3.76^{b}$ & $54.6^{\mathrm{b}}$ \\
\hline & 3.5 & & 50.7 & 123 & $4.32^{\mathrm{a}}$ & $55.3^{a}$ \\
\hline RMSE & & & 36.6 & 38.1 & 1.26 & 7.44 \\
\hline \multirow[t]{4}{*}{ Czech Hen } & Cage & 3.0 & 19.2 & 65.1 & 1.95 & $47.3^{f}$ \\
\hline & & 3.5 & 13.2 & 65.4 & 2.29 & $51.6^{d}$ \\
\hline & Litter & 3.0 & 21.3 & 150 & 4.52 & $50.9^{d}$ \\
\hline & & 3.5 & 19.1 & 143 & 5.02 & $48.2^{\mathrm{e}}$ \\
\hline \multirow[t]{4}{*}{ Lohmann } & Cage & 3.0 & 88.2 & 116 & 3.48 & $61.8^{a}$ \\
\hline & & 3.5 & 81.0 & 110 & 3.87 & $60.4^{b}$ \\
\hline & Litter & 3.0 & 86.9 & 169 & 5.07 & $58.4^{c}$ \\
\hline & & 3.5 & 89.5 & 174 & 6.11 & $60.8^{b}$ \\
\hline RMSE & & & 11.2 & 10.3 & 0.33 & 6.04 \\
\hline Genotype & & & 0.001 & 0.001 & 0.001 & 0.001 \\
\hline Housing & & & 0.927 & 0.001 & 0.001 & 0.001 \\
\hline $\mathrm{Ca}$ & & & 0.959 & 0.560 & 0.002 & 0.033 \\
\hline Genotype x & ing $\times \mathrm{Ca}$ & & 0.784 & 0.365 & 0.451 & 0.001 \\
\hline
\end{tabular}

$\mathrm{a}, \mathrm{b}, \mathrm{c}, \mathrm{d}, \mathrm{e}, \mathrm{f}$ Means in the same column with unlike superscripts differ $P<0.05$.

RMSE: root mean square error.

Eggshell parameters for weight, percentage, thickness, strength and density (Table 3) were higher $(P$ $<0.001)$ in eggs laid by the LSL hens. Eggshell thickness $(P<0.003)$ and density $(P<0.002)$ were higher for hens kept on litter. Higher dietary $\mathrm{Ca}$ content increased eggshell weight $(P<0.001)$ while decreasing shell percentage $(P<0.002)$, thickness $(P<0.002)$ and shell density $(P<0.001)$. Eggs with the heaviest shells were produced by LSL hens kept on litter and fed $3.5 \% \mathrm{Ca}$. There was a significant interaction between genotype, housing and $\mathrm{Ca}$ level in shell weight. In contrast, the strongest shells were produced by $\mathrm{CH}$ hens housed in cages and fed 3.0\% $\mathrm{Ca}$ and in LSL hens kept on litter and fed 3.5\% $\mathrm{Ca}$. The eggshell strength was affected by an interaction $(P<0.033)$ of genotype, housing and feed Ca level. 
Table 3 Main effects of genotype, housing system and dietary calcium (Ca) level, and their interactions on eggshell parameters

\begin{tabular}{|c|c|c|c|c|c|c|c|}
\hline Factor & Item & $\begin{array}{l}\mathrm{Ca} \\
(\%)\end{array}$ & $\begin{array}{l}\text { Eggshell } \\
\text { weight (g) }\end{array}$ & $\begin{array}{c}\text { Eggshell } \\
\text { percentage } \\
(\%)\end{array}$ & $\begin{array}{c}\text { Eggshell } \\
\text { thickness } \\
(\mathrm{mm})\end{array}$ & $\begin{array}{c}\text { Eggshell } \\
\text { strength } \\
\left(\mathrm{g} / \mathrm{cm}^{2}\right) \\
\end{array}$ & $\begin{array}{c}\text { Eggshell } \\
\text { density } \\
\left(\mathrm{g} / 100 \mathrm{~cm}^{2}\right)\end{array}$ \\
\hline \multirow[t]{2}{*}{ Genotype } & Czech Hen & & $4.72^{b}$ & $11.4^{b}$ & $0.316^{\mathrm{b}}$ & $4137^{b}$ & $7.49^{b}$ \\
\hline & Lohmann & & $5.98^{\mathrm{a}}$ & $12.2^{\mathrm{a}}$ & $0.353^{\mathrm{a}}$ & $4357^{a}$ & $8.33^{a}$ \\
\hline RMSE & & & 0.60 & 0.91 & 0.028 & 903 & 0.58 \\
\hline \multirow[t]{2}{*}{ Housing } & Cage & & 5.31 & 11.8 & $0.330^{b}$ & 4216 & $7.81^{b}$ \\
\hline & Litter & & 5.39 & 11.9 & $0.339^{\mathrm{a}}$ & 4277 & $8.01^{a}$ \\
\hline RMSE & & & 0.77 & 0.95 & 0.031 & 905 & 0.65 \\
\hline \multirow[t]{2}{*}{$\mathrm{Ca}$} & 3.0 & & $5.33^{b}$ & $11.9^{\mathrm{a}}$ & $0.336^{\mathrm{a}}$ & 4334 & $7.93^{\mathrm{a}}$ \\
\hline & 3.5 & & $5.37^{\mathrm{a}}$ & $11.7^{\mathrm{b}}$ & $0.334^{b}$ & 4159 & $7.89^{b}$ \\
\hline RMSE & & & 0.76 & 0.95 & 0.031 & 905 & 0.65 \\
\hline \multirow[t]{4}{*}{$\begin{array}{l}\text { Czech } \\
\text { Hen }\end{array}$} & Cage & 3.0 & $4.55^{\mathrm{e}}$ & 11.6 & 0.318 & $4480^{a}$ & 7.45 \\
\hline & & 3.5 & $4.66^{\mathrm{e}}$ & 10.8 & 0.299 & $3665^{\mathrm{e}}$ & 7.18 \\
\hline & Litter & 3.0 & $5.01^{d}$ & 11.8 & 0.331 & $4254^{c}$ & 7.82 \\
\hline & & 3.5 & $4.66^{\mathrm{e}}$ & 11.4 & 0.317 & $4147^{d}$ & 7.54 \\
\hline \multirow[t]{4}{*}{ Lohmann } & Cage & 3.0 & $6.03^{b}$ & 12.2 & 0.350 & $4341^{\mathrm{b}}$ & 8.27 \\
\hline & & 3.5 & $5.99^{b}$ & 12.5 & 0.356 & $4378^{b}$ & 8.34 \\
\hline & Litter & 3.0 & $5.73^{c}$ & 12.1 & 0.346 & $4262^{c}$ & 8.17 \\
\hline & & 3.5 & $6.16^{\mathrm{a}}$ & 12.3 & 0.363 & $4445^{a}$ & 8.53 \\
\hline RMSE & & & 0.58 & 0.89 & 0.027 & 896 & 0.56 \\
\hline \multicolumn{3}{|l|}{ Genotype } & 0.001 & 0.001 & 0.001 & 0.002 & 0.001 \\
\hline \multicolumn{3}{|l|}{ Housing } & 0.601 & 0.096 & 0.003 & 0.694 & 0.002 \\
\hline \multicolumn{3}{|c|}{$\mathrm{Ca}$} & 0.001 & 0.002 & 0.001 & 0.603 & 0.001 \\
\hline \multicolumn{3}{|c|}{ Genotype $x$ Housing $x$ Ca } & 0.001 & 0.190 & 0.341 & 0.033 & 0.071 \\
\hline
\end{tabular}

$\mathrm{a}, \mathrm{b}, \mathrm{c}, \mathrm{d}, \mathrm{e}$ Means in the same column with unlike superscripts differ $P<0.05$.

RMSE: root mean square error.

The results of the tibia characteristics indicate that individual factors play an important role in tibia structure (Table 4). Genotype did not affect any of the tibia measurements significantly $(P>0.05)$, whereas laying hens kept on litter had heavier and stronger tibias, but with a lower Ca content. An increased feed $\mathrm{Ca}$ level resulted in heavier $(P<0.025)$ and longer $(P<0.001)$ tibias. Tibia strength was lower $(P<0.001)$ on the higher dietary $\mathrm{Ca}$ level, whereas tibia ash and $\mathrm{Ca}$ content were not affected. There were no significant interactions $(P>0.05)$ among the factors.

\section{Discussion}

The results of the study confirmed differences in all production parameters between LSL and $\mathrm{CH}$ hens. It is evident that intensive selection for egg production in LSL hens has resulted in higher rates of lay and egg size, which corresponds with the observations of Hocking et al. (2003), Krawczyk (2009) and Rizzi \& Chiericato (2010). Housing system had a considerable effect on feed and $\mathrm{Ca}$ intake as well as egg weight. In cages, the $\mathrm{FI}$ of $\mathrm{CH}$ was $57 \%$ that consumed by LSL hens in the same housing system, while the difference in $\mathrm{FI}$ on litter between genotypes was $8 \%$. The lower $\mathrm{FI}$ of $\mathrm{CH}$ compared with LSL could be related to their lower productivity. This corresponds with results by Rizzi \& Chiericato (2010). The extremely low FI by $\mathrm{CH}$ in cages could be the result of this breed's discomfort in cages. Data also indicate that the low $\mathrm{FI}$ in $\mathrm{CH}$ in cages reduced egg production, but did not influence eggshell or tibia parameters. Feed Ca level did not affect egg production, which is in agreement with the results of Bar et al. (2002), Castillo et al. (2004) and Cufadar et al. (2011), but is in contrast with those of Narváez-Solarte et al. (2006) and Safaa et al. (2008). 
Table 4 Main effects of genotype, housing system and dietary calcium (Ca) level, and their interactions, on tibia characteristics

\begin{tabular}{|c|c|c|c|c|c|c|c|c|}
\hline Factor & Item & $\begin{array}{c}\text { Diet Ca } \\
(\%)\end{array}$ & $\begin{array}{c}\text { Tibia } \\
\text { weight (g) }\end{array}$ & $\begin{array}{c}\text { Tibia } \\
\text { length } \\
(\mathrm{mm})\end{array}$ & $\begin{array}{c}\text { Tibia } \\
\text { thickness } \\
(\mathrm{mm})\end{array}$ & $\begin{array}{c}\text { Tibia } \\
\text { strength } \\
(\mathrm{N})\end{array}$ & $\begin{array}{c}\text { Tibia ash } \\
\text { content } \\
(\mathrm{g})\end{array}$ & $\begin{array}{c}\text { Tibia Ca } \\
\text { content } \\
\text { (g) }\end{array}$ \\
\hline \multirow[t]{2}{*}{ Genotype } & Czech Hen & & 5.16 & 114 & 6.94 & 453 & 56.3 & 35.4 \\
\hline & Lohmann & & 5.30 & 114 & 6.88 & 429 & 54.9 & 35.8 \\
\hline RMSE & & & 0.97 & 3.32 & 0.37 & 92.6 & 4.06 & 2.25 \\
\hline \multirow[t]{2}{*}{ Housing } & Cage & & $4.92^{b}$ & 114 & 6.98 & $397^{b}$ & 57.8 & $36.4^{a}$ \\
\hline & Litter & & $5.55^{\mathrm{a}}$ & 114 & 6.84 & $485^{a}$ & 56.4 & $34.8^{b}$ \\
\hline RMSE & & & 0.93 & 4.05 & 0.36 & 83.8 & 3.99 & 2.10 \\
\hline \multirow[t]{2}{*}{$\mathrm{Ca}$} & 3.0 & & $4.92^{b}$ & $111^{b}$ & 6.90 & $493^{a}$ & 56.6 & 35.5 \\
\hline & 3.5 & & $5.55^{a}$ & $117^{\mathrm{a}}$ & 6.91 & $389^{b}$ & 54.6 & 35.7 \\
\hline RMSE & & & 0.95 & 4.01 & 0.37 & 84.9 & 3.86 & 2.25 \\
\hline \multirow[t]{4}{*}{ Czech Hen } & Cage & 3.0 & 5.38 & 111 & 6.98 & 473 & 57.2 & 35.0 \\
\hline & & 3.5 & 4.53 & 118 & 6.99 & 327 & 53.3 & 35.9 \\
\hline & Litter & 3.0 & 5.78 & 111 & 7.03 & 521 & 58.2 & 35.3 \\
\hline & & 3.5 & 5.40 & 117 & 7.75 & 490 & 56.5 & 35.7 \\
\hline \multirow[t]{4}{*}{ Lohmann } & Cage & 3.0 & 4.97 & 110 & 6.85 & 474 & 53.9 & 37.8 \\
\hline & & 3.5 & 4.78 & 116 & 7.09 & 311 & 54.2 & 37.2 \\
\hline & Litter & 3.0 & 6.05 & 111 & 6.76 & 499 & 57.2 & 34.2 \\
\hline & & 3.5 & 4.85 & 118 & 6.82 & 429 & 54.1 & 34.1 \\
\hline RMSE & & & 0.91 & 2.62 & 0.37 & 60.1 & 3.95 & 1.93 \\
\hline \multicolumn{3}{|l|}{ Genotype } & 0.594 & 0.669 & 0.582 & 0.175 & 0.239 & 0.275 \\
\hline \multicolumn{3}{|l|}{ Housing } & 0.022 & 0.179 & 0.189 & 0.001 & 0.166 & 0.001 \\
\hline \multicolumn{3}{|l|}{$\mathrm{Ca}$} & 0.025 & 0.001 & 0.911 & 0.001 & 0.099 & 0.615 \\
\hline \multicolumn{3}{|c|}{ Genotype $x$ Housing $x \mathrm{Ca}$} & 0.142 & 0.394 & 0.814 & 0.807 & 0.193 & 0.448 \\
\hline
\end{tabular}

a,b Means in the same column with unlike superscripts differ $P<0.05$.

RMSE: root mean square error.

These inconsistent results can be related to variable genotypes, age and Ca levels in these studies. Increasing feed $\mathrm{Ca}$ level did not affect feed intake, but significantly increased $\mathrm{Ca}$ intake. The results indicate that laying hens can tolerate high levels of $\mathrm{Ca}$, as observed by Keshavarz \& Nakijama (1993). The higher Ca level resulted in increased egg weight, which is in contrast with the results of Castillo et al. (2004), Valkonen et al. (2010) and Cufadar et al. (2011), who reported that Ca level had no effect on egg weight. The difference in results could be because of the significant interaction between genotype, housing and feed $\mathrm{Ca}$ level, all of which appeared to play an important role in this trait. The $\mathrm{CH}$ hens produced heavier eggs on $3.5 \% \mathrm{Ca}$ in cages, whereas on litter the heaviest eggs were produced on $3.0 \% \mathrm{Ca}$. Presumably, in the $\mathrm{CH}$ genotype housed in cages, a higher dietary Ca level compensated for the low feed intake (3.85 vs. $3.48 \mathrm{~g}$ $\mathrm{Ca} / \mathrm{d})$. However, the combination of high $\mathrm{Ca}$ content and a high feed intake in hens on litter resulted in an additional $0.5 \mathrm{~g} \mathrm{Ca}$ intake per day (4.52- $5.02 \mathrm{~g})$. This presumably led to a reduction in the ingestion of other nutrients, resulting in lower egg weight. This theory corresponds with that of Bar et al. (2002), who observed that increasing $\mathrm{Ca}$ intake from 3.6 to $5.02 \mathrm{~g}$ decreased egg weight. LSL hens in cages compensated for the lower feed $\mathrm{Ca}$ level by increasing feed intake, which corresponds with the findings of Narváez-Solarte et al. (2006). On the other hand, on litter, a higher feed intake balanced out lack of other nutrients, which affected egg weight more than rate of lay.

For all the eggshell characteristics, higher values were observed in LSL, which can be attributed to a result of long-term selection for these characteristics. This corresponds with the results of Anderson et al. (2004), Krawczyk (2009), and Rizzi \& Marangon (2012), who reported that commercial genotypes have better eggshell quality than traditional breeds. However, Hocking et al. (2003) observed relatively little genetic variation in eggshell strength, and no detectable differences between breeds in hens that were 55 
weeks old. Our study evaluated eggshell strength over a longer period, between the 40th and 60th week of age. Housing system did not affect many of the eggshell quality measurements. No differences were found in eggshell weight, eggshell percentage or strength between eggs from the two housing systems, namely cages and litter, which corroborates the work of Tůmová et al. (2011) and Englmaierová et al. (2014). However, thicker shells and higher shell density were observed on litter. Yan et al. (2014) observed that eggs with thicker, but less uniform shells resulted in lower shell strength. This relationship is assumed to be the result of correlations between eggshell traits. Low correlations exist between eggshell weight and strength or thickness and strength (Rodriguez-Navarro et al., 2002; Tưmová \& Ledvinka, 2009). Blanco et al. (2014) reported correlations between eggshell strength and thickness $(0.50-0.63)$ and stated that these moderate relationships demonstrate that the strength of an egg does not rely on shell thickness alone, but on the quality and uniformity of eggshell construction. The results in the present study indicate that $3.5 \%$ feed Ca resulted in a $\mathrm{Ca}$ intake of $4.32 \mathrm{~g} / \mathrm{d}$, which is too high to be beneficial to eggshell quality, corresponding with the findings of Safaa et al. (2008). In addition, a significant interaction was found between genotype, housing and $\mathrm{Ca}$ in eggshell weight and strength. This interaction plays an important role mainly in eggshell strength, which is a function of shell structural integrity.

The tibia measurements were unaffected by genotype or the interactions between genotype, housing and Ca level. On the contrary, Hocking et al. (2003) observed that 55-week-old commercial layers had lighter, weaker and less stiff tibias than traditional breeds. These results are in contrast with their following study (Hocking et al., 2009), in which no differences in tibia quality were found between commercial layers and traditional breeds. The discrepancy between the two studies could not be explained. The lack of difference in tibia characteristics between genotypes in the present study indicates similar Ca metabolism in the two genotypes. This corresponds with Hocking et al. (2003), who suggested that the absence of differences is likely to be normal developmental consequences of the greater weight of the traditional birds. In hens housed on litter, tibia weight and strength were higher, which corresponds with findings by Abrahamson \& Tauson (1997), Leyendecker et al. (2001), Lichovníková \& Zeman (2008) that higher values for tibia measurements on litter are associated with greater activity. Lower tibia Ca content indicates that the increased $\mathrm{Ca}$ consumption in this housing system presumably resulted in a higher Ca excretion (Świątkiewicz et al., 2015). The theory can be linked to the Ca intake on litter, which was about 55\% higher than in cages. The lower tibia Ca content and higher strength corresponds with results from work by Cufadar et al. (2011), who observed that increasing dietary $\mathrm{Ca}$ increased tibia strength, but decreased tibia Ca content. The higher dietary $\mathrm{Ca}$ level resulted in higher tibia weight and length, but lower tibia strength, whereas $\mathrm{Ca}$ content was not affected. These results support the assumption above because higher dietary $\mathrm{Ca}$ increased $\mathrm{Ca}$ intake by about $14 \%$ compared with lower dietary $\mathrm{Ca}$. Therefore it was not beneficial to tibia strength and did not affect tibia Ca content, which corresponds with the findings of Safaa et al. (2008) and Jiang et al. (2013).

\section{Conclusion}

The results of this study show large differences in performance and eggshell quality with respect to genotypes, housing and Ca levels. With regard to the housing system, ultrastructural differences in eggshell structure are assumed. A higher Ca level led to lower bone turnover, which resulted in improved tibia weight, length and thickness, but not in tibia strength. Of particular importance were the significant interactions among these factors in the variables, which need to be considered when determining the way in which these two laying strains are fed.

\section{Acknowledgement}

The study was supported by the Ministry of Agriculture of the Czech Republic (Project NAAR No. QJ 1310002).

\section{Authors' Contributions}

$\mathrm{JV}, \mathrm{VCH}, \mathrm{MK}$ conducted the experiment as a part of their PhD programme, OD, VT contributed for the tibia analyses, $\mathrm{DCH}$ was responsible for the statistical evaluation and supervising of the experiment, ET designed and analysed the experiment and wrote the paper.

\section{Conflict of Interest Declaration}

The authors declare that there is no conflict of interests.

\section{References}

Abrahamsson, P. \& Tauson R., 1997. Effect of group size on performance, health and birds' use of facilities in furnished cages for laying hens. Acta Agric. Scand. Section A-Animal Science. 47, 254-260. 
Ahmed, A.M.H., Rodriguez-Navarro, A.B., Vidal, M.L., Gautron, J., Garcia-Ruiz, J.M. \& Nys, Y., 2005. Changes in eggshell mechanical properties, crystallographic texture and in matrix proteins induced by moult in hens. Br. Poult. Sci. 46, 268-279.

Anderson, K.E., Tharrington, J.B., Curtis, P.A. \& Jones, F.T., 2004. Shell characteristics of eggs from historic strains of single comb white leghorn chickens and the relationship of egg shape to shell strength. Int. J. Poult. Sci. 3, 17-19.

AOAC, 2005. Official Methods of Analysis, 18th ed. Association of Official Analytical. Chemists, Maryland, USA.

Bar, A., Razaphkovsky, V. \& Vax, E., 2002. Re-evaluation of calcium and phosphorus requirements in aged laying hens. Br. Poult. Sci. 43, 261-269.

Blanco, A.E., Icken, W., Ould-Ali, D., Cavero, D. \& Schmutz, M., 2014. Genetic parameters of egg quality traits on different pedigree layers with special focus on dynamic stiffness. Poult. Sci. 93, 2457-2463.

Castillo, C., Cuca, M., Pro, A., González, M. \& Morales, E., 2004. Biological and economic optimum level of calcium in white leghorn laying hens. Poult. Sci. 83, 868-872.

Cheng, T.K. \& Coon, C.N., 1990. Effect of calcium source, particle size, limestone solubility in vitro and calcium intake level on layer bone status and performance. Poult. Sci. 69, 2214-2219.

Cufadar, Y., Olgun, O. \& Ö. Yildiz, A., 2011. The effect of dietary calcium concentration and particle size on performance, eggshell quality, bone mechanical properties and tibia mineral contents in moulted laying hens. Br. Poult. Sci. 52, 761-768.

Englmaierová, M., Tưmová, E., Charvátová, V. \& Skřivan, M., 2014. Effects of laying hens housing system on laying performance, egg quality characteristics, and egg microbial contamination. Czech J. Anim. Sci. 59, 345-352.

Farmer, M., Roland, D.A. \& Clark, A.J., 1986. Influence of dietary calcium on bone calcium utilization. Poult. Sci. 65, 337-344.

Hocking, P.M., Bain, M., Channing, C.E., Fleming, R. \& Wilson, S., 2003. Genetic variation for egg production, egg quality and bone strength in selected and traditional breeds of laying fowl. Br. Poult. Sci. 44, 365-373.

Hocking, P.M., Sandercock, D.A., Wilson, S. \& Fleming, R.H., 2009. Quantifying genetic (co) variation and effects of genetic selection on tibial bone morphology and quality in 37 lines of broiler, layer and traditional chickens. Br. Poult. Sci. 50, 443-450.

Holt, P.S., Davies, R.H., Dewulf, J., Gast, R.K., Huwe, J.K., Jones, D.R., Waltman, D. \& Willian, K.R., 2011. The impact of different housing systems on egg safety and quality. Poult. Sci. 90, 251-262.

Jiang, S., Cui, L., Shi, CH., Ke, X., Luo, J. \& Hou, J., 2013. Effects of dietary energy and calcium levels on performance, eggshell quality and bone metabolism in hens. Vet. J. 198, 252-258.

Keshavarz, K. \& Nakajima, S., 1993. Re-evaluation of calcium and phosphorus requirements of laying hens for optimum performance and eggshell quality. Poult. Sci. 72, 144-153.

Kim, W.K., Bloomfield, S.A., Sugiyama, T. \& Ricke, S.C., 2012. Concepts and methods for understanding bone metabolism in laying hens. Wrld. Poult. Sci. J. 68, 71-82.

Krawczyk, J., 2009. Effect of layer age and egg production level on changes in quality traits of eggs from hens of conservation breeds and commercial hybrids. Ann. Anim. Sci. 9, 185-193.

Leyendecker, M., Haamann, H., Hartung, J., Kamphues, J., Ring, C., Glünder, G., Ahlers, C., Sander, I., Neumann, U. \& Distl, O., 2001. Analysis of genotype-environment interactions between layer lines and hen housing systems for performance traits, egg quality and bone breaking strength -2nd communication: Egg quality traits. Züchtungskunde 73, 290-307.

Leyendecker, M., Haamann, H., Hartung, J., Kamphues, J., Neumann, U., Sürie, C. \& Distl, O., 2005. Keeping laying hens in furnished cages and an aviary housing system enhances their bone stability. Br. Poult. Sci. 46, 536-544.

Lichovníková, M. \& Zeman, L., 2008. Effect of housing system on the calcium requirement of laying hens and eggshell quality. Czech J. Anim. Sci. 53, 162-168.

Narváez-Solarte, W., Rostagno, H.S., Soares, P.R., Uribe-Velasquez, L.F. \& Silva, M.A., 2006. Nutritional requirement of calcium in white laying hens from 46 to 62 wk of age. Int. J. Poult. Sci. 5, 181-184.

Nascimento, G.R., Murakami, A.E., Guerra, A.F.Q.M., Ospinas-Rojas, I.C., Ferreira, M.F.Z. \& Fanhani, J.C., 2014. Effect of different vitamin D sources and calcium levels in the diet of layers in the second laying cycle. Braz. J. Poult. Sci. 16, 37-42.

Neijat, M., House, J.D., Guenter, W. \& Kebreab, E., 2011. Calcium and phosphorus dynamics in commercial laying hens housed in conventional or enriched cage systems. Poult. Sci. 90, 2383-2396.

NRC, 1994. Nutrient Requirements for Poultry. 9th ed. National Academy Press, Washington, D.C., USA.

Rizzi, C. \& Chiericato, G.M., 2010. Chemical composition of meat and egg yolk of hybrid and Italian breed hens reared using an organic production system. Poult. Sci. 89, 1239-1251.

Rizzi, C. \& Marangon, A., 2012. Quality of organic eggs of hybrid and Italian breed hens. Poult. Sci. 91, $2330-2340$.

Rodriguez-Navarro, A., Kalin, O., Nys, Y. \& Garcia-Ruiz, J.M., 2002. Influence of the microstructure on the shell strength of eggs laid by hens of different ages. Br. Poult. Sci. 43, 395-403.

Safaa, H.M., Serrano, M.P., Valencia, D.G., Frikha, M., Jimenéz-Moreno, E. \& Mateos, G.G., 2008. Productive performance and egg quality of brown egg-laying hens in the late phase of production as influenced by level and source of calcium in the diet. Poult. Sci. 87, 2043-2051.

SAS, 2013. Statistical Analysis System for Windows. Release 9.4. SAS Institute Inc., Cary, North Carolina, USA.

Şekeroğlu, A., Duman, M., Tahtali, Y., Yildrim, A. \& Eleroğlu, H., 2014. Effect of cage tier and age on performance, egg quality and stress parameters of laying hens. S. Afr. J. Anim. Sci. 44, 288-297.

Singh, R., Cheng, K.M. \& Silversides, F.G., 2009. Production performance and egg quality of four strains of laying hens kept in conventional cages and floor pens. Poult. Sci. 88, 256-264. 
Świątkiewicz, S., Arczewska-Wlosek, A. \& Jozefiak, D., 2015. Bone quality, selected blood variables and mineral retention in laying hens fed with different dietary concentrations and sources of calcium. Livest. Sci. 181, 194-199.

Thomson, B.K., Hamilton, R.M.G. \& Grunder, A.A., 1985. The relationship between laboratory measures of eggshell quality and breakage in commercial egg washing and candling equipment. Poult. Sci. 64, 901-909.

Tůmová, E. \& Ledvinka, Z., 2009. The effect of time of oviposition and age on egg weight, egg components weight and eggshell quality. Arch. Geflügelkde 72, 110-115.

Tůmová, E., Englmaierová, M., Ledvinka, Z. \& Charvátová, V., 2011. Interaction between housing system and genotype in relation to internal and external egg quality parameters. Czech J. Anim. Sci. 56, 490-498.

Valkonen, E., Venäläinen, E., Rossow, L. \& Valaja, J., 2010. Effects of calcium diet supplements on egg strength in conventional and furnished cages, and effects of 2 different nest floor materials. Poult. Sci. 89, 2307-2316.

Van den Brand, H., Parmentier, H. \& Kemp, K., 2004. Effect of housing system (outdoor vs. cages) and age of laying hens on egg characteristics. Br. Poult. Sci. 45, 745-752.

Yan, Y.Y., Sun, C.J., Lian, L., Zheng, J.X., Xu, G.Y. \& Yang, N., 2014. Effect of uniformity of eggshell thickness on eggshell quality in chickens. J. Poult. Sci. 51, 338-342. 